\title{
Japan finds clams and trouble
}

Tokyo

ON its second dive to the Tenryu Canyon off the Pacific coast of Japan, the French deep-sea submersible Nautile struck gold with the discovery of colonies of giant clams at a depth of $3,830 \mathrm{~m}$, the deepest record so far of "vent communities" of organisms. But no sooner did news of the find break than Nautile sustained serious damage when surfacing in rough seas. Repairs to the submersible will probably take at least a month and may require the postponement of the Franco-Japanese project Kaiko until next year.

The colonies of clams were found on 6 June by Professor Claude Rangin of the University of Paris during a dive to the deep-sea fan at the mouth of the Tenryu Canyon, a steep-sided submarine valley that cuts into the accretion wedge of sediments being stacked up along the edge of the Eurasian plate as the subducting Philippine plate plunges beneath Japan. The giant clams are up to $15 \mathrm{~cm}$ in length and have been provisionally identified by Dr Suguru Ohta of the Ocean Research Institute, University of Tokyo, as Calyptogena sp., a genus of bivalve typical of the "vent communities" of organisms reported from mid-ocean spreading ridges and the subduction zone off the coast of Oregon.

According to Asahiko Taira, professor of sedimentology at the Ocean Research Institute, who made a dive to the clam site on 10 June, the colonies of Calyptogena sp. are circular, up to $60 \mathrm{~cm}$ in diameter and contain phenomenal densities of clams stacked on top of each other. One box core $250 \mathrm{~cm}^{2}$ in cross-sectional area is said to have contained about 40 living clams, and during sampling some were crushed in the jaws of the box core releasing clouds of bright red blood. (The blood of vent organisms typically contains large amounts of haemoglobin.) On opening the box core on deck, a putrid smell was given off that made everyone feel sick, but hydrogen sulphide, which provides the "life-blood" of vent communities at spreading ridges, has not been found in anomalous amounts within the core and overlying waters, according to Dr Taira.

The colonies are aligned along northeast/south-west trending reverse faults associated with subduction and to a lesser extent along north/south strike-slip faults. The Tenryu Canyon runs along a major north/south transcurrent fault system which cuts into the mainland of Japan along the valley of the Tenryu River. Water inside the colonies shows positive thermal anomalies of a few tenths of a degree centigrade which may arise from connate water upwelling along the fault planes as the accretion prism of sediments flanking Japan is "squeezed" by subduction. The clam colonies thus in many rein the subduction zone off the Oregon/ Washington coast, where it has been suggested that the vent organisms are powered by oxidation of methane contained in upwelling "old seawater" derived from underlying sediments (see Nature 313, 339; 1985).

Other organisms found in the vicinity of the clam colonies include squat lobsters, gastropods, several of sea anemone and polychaete worms, but no giant tube worms have yet been found. Dr Ohta hopes to present the preliminary biological findings at an international symposium on deep-sea biology to be held in Hamburg, West Germany, next week. The specimens have been divided equally between the French and Japanese.
Cameramen from the Japanese national broadcasting corporation, NHK, will now be allowed to make two dives on the Nautile to film the seafloor. Japan's biologists, who have not been included in the dive schedule despite predictions that "vent communities" might be found (see Nature 313; 1985), hope that NHK will choose to film the Tenryu Canyon clam colonies and perhaps collect some more specimens.

All this, however, depends upon Nautile being repaired in time to resume operations this summer. The electrical circuit of the submersible has been damaged and technicians and equipment must be flown out to Japan from France. At worst the Kaiko project may have to be delayed until next year, which could be a blessing in disguise as it would open a way for biologists to participate in the project. A decision on the future of Kaiko is expected this week.

\section{Soviet science}

\section{Gorbachev calls for new reform}

ACADEMIC institutes in the Soviet Union must be "turned around sharply" to concentrate on research which is "technological in its thrust", the Soviet Party leader, Mikhail Gorbachev, told the Central Committee last week. Among other things, he proposed the establishment, within the Soviet Academy of Sciences, of "integrated, inter-industry scientific and technical centres".

This, in effect, would reverse Khrushchev's reform of almost 25 years ago, when its academy was stripped of its applied science institutes. Since 1976 , party plans and directives have increasingly called for the academy to play a greater role in "coordinating" the implementation of research. Industrial centres of the type proposed by Gorbachev have already been established; one example is the Paton Electric Welding Institute under the aegis of the Ukrainian Academy of Sciences. This experience, Gorbachev suggested, should now be applied at the all-union level.

This turnabout would not, however, mean a decline of interest in pure research. On the contrary, said Gorbachev, it must be given priority, with no quarter given to "weakness" or "sluggishness". The research potential of the universities, in particular, must be better deployed. According to "available assessments", Gorbachev said, higher education establishments could increase the volume of their research by between 100 and 150 per cent (presumably without additional resources). Gorbachev's emphasis on the academy and university sectors is due, it appears, to the poor performance of the research establishments of the various production ministries. The Soviet Union spends 5 per cent of the national income on science almost 90 per cent of that in ministry institutes. More than half of all Soviet scientists work in them, and, according to Gorbachev, many of them, notably the Ministry of the Chemical Industry, have become "overgrown", with too many scientific institutes and pilot plants. Yet these are precisely the industries where there have been major shortcomings in developing new materials.

In his speech last week, Gorbachev complained that too many administrators, instead of finding a proper solution to a problem, shelve the issue by explaining that they are "carrying out an experiment", Gorbachev's answer is to strengthen the State Planning Committee, and to put into practice Lenin's dictum that the committee must be transformed into the country's "economic science organ, gathering together major scientists and leading specialists".

On the practical side, he urged that since the main weakness of Soviet industrial research lies in its isolation from production, many of the so-called "industrial" institutes should be immediately amalgamated with production enterprises. An immediate review should be carried out of how far the applied research institutes correspond to the current needs of industry.

Gorbachev also urged that something should be done about the declining prestige of engineers and the falling recruitment of talented young people into the technical sciences, which seems to have alarmed the Academy of Sciences. Gorbachev offers no immediate solution, but suggested that it may be time for a "serious reorganization" of higher education, meanwhile urging "measures to raise the social recognition" of engineers and technologists, including new pay deals.

Vera Rich 